\title{
Teacher Communication in Teaching Al-Quran to Special Needs Pupils with Hearing Disabilities
}

\author{
Izuli Dzulkifli ${ }^{1, *}$, Asmawati Suhid ${ }^{2}$, Fathiyah Mohd Fakhruddin², Nor Aniza Ahmad ${ }^{3}$ \\ ${ }^{1}$ Centre for Islami Sustainability, Faculty of Islamic Studies, Universiti Kebangsaan Malaysia (UKM), 43600 UKM Bangi, Selangor, Malaysia \\ ${ }^{2}$ Department of Language and Humanities Education, Faculty of Education Studies, Universiti Putra Malaysia (UPM), Serdang, Selangor, Malaysia \\ ${ }^{3}$ Department of Foundations of Education, Faculty of Education Studies, Universiti Putra Malaysia (UPM), Serdang, Selangor , Malaysia
}

Received October 27, 2019; Revised December 2, 2019; Accepted December 24, 2019

Copyright $\bigcirc 2020$ by authors, all rights reserved. Authors agree that this article remains permanently open access under the terms of the Creative Commons Attribution License 4.0 International License

\begin{abstract}
People with hearing disabilities especially pupils with special needs have their own form of communication. The learning of the Al-Quran, which is one of the components in Islamic Education, focuses on three main aspects: reading, memorization and comprehension. Since the level of hearing and speech impairment of the pupils with special needs are limited, it is essential that the communication aspect in teaching should be taken into the teachers' consideration. The objective of this study is to explain the form of communication used by the hearing impaired in Malaysia as well as the method of communication used by teachers in teaching them the Al-Quran. This study utilized the qualitative approach in the form of a case study, using the interview technique and document analysis to obtain data. This study also utilized the model of communication presented by Bernice Burnip in Louise Porter. Some of the findings showed there were inconsistencies in the teachers' communication in delivering the Al-Quran to the pupils. Lack of proper codes or signs in studying the Al-Quran was one of the reasons for lack of communication between the teachers and pupils with hearing impairment. Hence, an appropriate and effective communication system should be studied so that pupils with hearing disabilities are not being left behind in learning the Al-Quran.
\end{abstract}

Keywords Communication System, Pupils with Special Needs, Hearing Disabilities, Al-Quran

\section{Introduction}

The language needs of the hearing impaired are as important as the language needs of normal children. Everyone needs language to convey one's intentions and feelings, despite the obvious differences between verbal and non-verbal communications. Sign language is the first language of deaf people formed by the deaf people themselves for the purpose of communication among themselves. This sign language is a visual and movement-oriented communication system. The deaf people in the United States use American Sign Language (ASL) to communicate (Grushkin, 2006 \& Ciara Kelly, 2019). The use of ASL is also widely used in the US education system including in the fields of Science, Mathematics and Social Sciences. Several studies in America have demonstrated the importance of effective communication to relay information to the deaf and hearing impaired including children. Deaf and hearing-impaired children have communication difficulty during classroom learning (Antia, 2007). Carol Marchetti et. al (2012) in their study stated teachers can use various communication methods to achieve the learning outcomes of deaf pupils. Teachers who teach deaf and hearing impaired pupils need to have communication skills to assist in the improvement of pupils' achievement in learning (Shirin D et al. 2009, Antia, Sabers, \& Stinson, 2007).

A study in Iran showed some effects of poor communication on 32 deaf respondents between the ages of 18 and 55. The study showed the impact of poor communication on many areas which caused problems among the deaf, including in education (Zohreh Ghari, 2016). In Pakistan, the oral approach was used in the classroom teaching. Meanwhile, the Pakistani Sign Languange (PSL) was differently utilized in various areas (Bushra Akram \& Rukhsana Bashi, 2013). Communication training is very important for teachers in improving their teaching skills to deliver information and syllabus to deaf pupils. Studies in Pakistan showed teachers in Special Education schools were incapable of using the PSL properly during lessons. Eighty-eight percent $(88 \%)$ of Pakistani teachers did not use finger spelling and $90 \%$ of the teachers did not use Cued Speech in the classroom (Khatoon, 2003). In Indonesia, in 
the Islamic education, there were two main methods of communication. The first method used was the manual method of Sign Language with finger spelling. The second method emphasized on speech and lip reading exercises (Ns. Mardiyanti and Luh Putu Suta Haryanthi, 2018).

As in other countries, the deaf people in Malaysia also have their own Sign Language to communicate. The Malaysian Sign Language (BIM) is used by the Malaysian deafs in their daily life. The use of BIM in the government National School of Special Education and in schools that provide Special Education Integrated Program is limited, and even peripheral. The Malaysian Sign Language (BIM) is applied in the form of mobile or information technology to assist deaf pupils in learning the Malay language (Mat Redhuan Samsudin et al. (2018).

In Malaysia, pupils with special needs are certified as having hearing disabilities by medical practitioners, opticians, audiologists or psychologists either in the government or private services (Federal Government Regulation 2013). However, the most commonly used term under the 'Code of Practice on Education is, Pupils with Special Educational Needs'. Usually pupils with special educational needs have hearing disabilities as well as speech, language and communication disabilities. One of the disadvantages of communicating with pupils with special educational needs is hearing impairment which will affect their learning process (Safani Bari et. al, 2005). Therefore, effective communication is very important in education especially for children in primary schools (Asmawati et. al, 2014). Pupils with disability in learning the Al-Quran in the Islamic Education subject at the primary level are placed in the Special Education Intergrated Programme (PPKI) and Special Primary Schools (SKPK). Malaysia's education system requires Muslim students to take Islamic Education subjects. The Education Act 1996 (Act 550, Section 50), stipulated that if there are five or more educational institutions have five or more Muslim students, teachers should teach Islamic Education as approved by the State Authority (Special Education Information 2007). According to the Act, there is no exception for pupils with special educational needs in learning the Al-Quran which is one of the components of the Islamic Education.

Teaching and Learning the Al-Quran has its own characteristics compared to other sciences in Islamic Education. Teaching the Al-Quran involves verbal skills, reading fluency, communication skills, verbal and non-verbal skills (Ministry of Education Malaysia 2004b). Having a mentor in learning the Al-Quran is the most effective technique which had been practised through ancient times until today. The main technique used in studying the Al-Quran via mentor is the Talaqqi or Mushafahah which means listening and reciting the Al-Quran, guided by the teacher. It is done by the either the teacher showing the method of reciting initially and followed by the pupils or the pupils recite and the teacher listens and corrects. However, the ability of the pupils with hearing disabilities to receive sound and information during Quranic recitation is extremely difficult. They could not recite the Al-Quran due to the hearing loss, the most important sense in receiving information. Therefore, appropriate sign language should be applied to the Al-Quran learning, the strategy adopted should also be applicable to any combination of disabilities to ensure there are no-drop-outs.

As pupils with hearing disabilities are not able to communicate well, the question of the method of communication used by teachers during Al-Quran learning should be taken into consideration. The Arabic language is used in reading the Al-Quran. In the Malaysian education system, Arabic is considered as a foreign or second language. Therefore, the discussion related to the study of the Al-Quran has its own perspective based on second language learning theory (Kamarulzaman et. al, 2002). The main difficulty faced by pupils with hearing impairment is the disability to detect and receive sound. Therefore, the use of sign language is their main medium of communication. In terms of language acquisition and information, it is found deaf pupils are left far behind. They have communication difficulties among themselves as well as with normal pupils (Abdullah, 2001). Therefore, an appropriate communication system should be implemented to produce effective teaching for pupils with special needs in learning the Al-Quran.

The objective of this study is to determine the type of communication used by pupils with hearing disabilities in Malaysia and to determine the communication method used by the teachers in teaching the AL-Quran.

\section{Method}

This study utilized the qualitative approach i.e. a case study. The instruments used included semi-structured interviews and document analysis to obtain data. Tables 1 and 2 indicate seven respondents were selected based on purposive sampling, of whom five were teachers who taught the Al-Quran to the pupils with special educational needs in Selangor. The selection of the respondents was based on specific criteria where teachers had at least five years of experience in teaching the Al-Quran. Two officers from Special Education, Ministry of Education Malaysia who were involved in the Special Islamic Education and Special Education Curriculum unit were selected to support the findings. 
Table 1. Teacher's Demographic Background

\begin{tabular}{|c|c|c|c|c|}
\hline Teacher & Sex & Age & Experience & School Category \\
\hline T1 & Female & 40 & 19 Years & *PPKI \\
\hline T2 & Female & 43 & 10 Years & *PPKI \\
\hline T3 & Female & 36 & 10 Years & *PPKI \\
\hline T4 & Female & 48 & 5 Years & *PPKI \\
\hline T5 & Male & 32 & 6 Years & *SKPK \\
\hline
\end{tabular}

** Special Education Intergrated Programme (PPKI)

*Special Primary Schools (SKPK)

Table 2. Officer's Demographic Background

\begin{tabular}{|c|c|c|c|c|}
\hline Officer & Sex & Age & Position & Unit/Division \\
\hline O1 & Male & 50 & $\begin{array}{c}\text { Head of } \\
\text { Department }\end{array}$ & $\begin{array}{c}\text { Islamic and Moral } \\
\text { Education }\end{array}$ \\
\hline O2 & Female & 52 & Section Head & $\begin{array}{c}\text { Curriculum } \\
\text { Development }\end{array}$ \\
\hline
\end{tabular}

The communication model presented by Bernice Burnip in Louise Porter (2002: 154) was used in this study. According to Bernice Burnip, communication is the act of exchanging ideas, ideas, needs and desires. He also stated that speech and language are part of the communication process. There are several components involved in communication. Bernice (2002) had classified it into non-verbal and verbal. This shows that communication can be done as non-verbal, by showing facial expressions, body gestures and so on. While verbal communication involves languages such as semantics, structure and pragmatic (Figure 1).

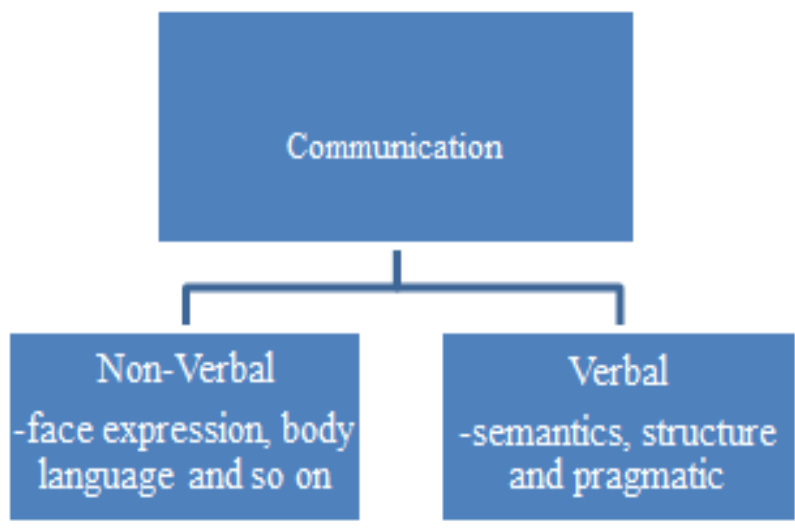

Figure 1. Communication Model by Bernice Burnip (2002)

From the Burnice Burnip model, it can be understood that communication for special needs pupils with hearing disabilities can be conveyed via three main methods: oral, manual and combination of both oral and manual. The oral method involves auditory-verbal and speech therapy (speech reading), and the manual method involves the use of handwriting, sign language and fingerprinting. While a combination of verbal and gestural methods produces cued speech and total communication.

\section{Findings}

\subsection{Form of Communication Used by Pupils with Hearing Disabilities in Malaysia}

\section{a. Oral}

The oral method was first used at Penang Federal School (Chua 1976). In oral language, teaching was done using speech, lip reading and writing (Chua 1980). This method prefers speech rather than signs and speech must be taught to learn the language. However, the method was used for only 20 years and was renamed as Total Communication method. According to Greenberg et al. (Bee 1995), deaf pupils would have difficulty in speaking or reading if the oral language was solely emphasized. The result would be different if they were taught the sign language, lip reading and spoken language simultaneously. Oral methods could help deaf pupils read lips, but they only understood the movement of the lips and not the actual meaning. This would cause them to be deaf forever.

\section{b. Total Communication}

When the oral method became a failure, it was replaced by the Total Communication method. This method was first introduced at Maryland School Frederick, USA. It was also found this method was suitable in the education of deaf pupils and had been introduced in Malaysia. According to Fisher (1982), Total Communication is a form of gesture communication that uses the fingers, arms, hands, facial expression and body movements. Manually Coded Malay is a form of communication language that is built based on Total Communication and the code system was built based on the Malay language principle that everyone hears, speaks, writes, read and understand. Patsy (1995) stated the use of the Manually Coded Malay could explain two meanings for a word and it is very important to the deaf pupils as they can acquire language through communication. 


\section{c. Cued Speech}

Cued speech was found by R. Orin Cornett (1966). This method is a combination of oral-aural pronunciations and syllable structure (clear visual representation of language). This method uses eight hand shapes and three hand positions. It was first used in 1992 at the Sultan Alam Shah Primary School in Petaling Jaya. Patsy (1995) stated that Cued Speech is a great language-learning tool for deaf pupils. This method does not receive favorable response and is found only to be used by certain parties such as non-governmental organizations (NGOs) that provide education classes to deaf pupils.

\section{d. Verbal Auditory}

This is another method introduced in Malaysia to convey information to the hearing impaired. This approach is used to encourage and train deaf pupils to hear either through hearing aid or through a "cochlear implant" to learn language. (Kartini Ahmad 1997). In Malaysia Verbal Auditory methods are relatively new and require strong and organized support to be implemented. Robinson (1998) found children who used cochlear implants showed better performance than children who used hearing aids. Children who used a cochlear implant at the preschool age were more likely to attend normal schools compared to children who used hearing aids. According to Simser (1997) there are four main principles of Verbal Auditory methods; Individual diagnostic therapy with parental involvement, speech use, natural development and language learning through natural and meaningful interactions.

\subsection{Communication Methods Used by Teachers in Teaching the Al-Quran to Special Needs Pupils with Hearing Disabilities.}

\section{a. Oral (Speech)}

As mentioned earlier, some special needs pupils with hearing disabilities have hearing loss but can speak. So, for pupils who can speak and recite, should be taught orally so that they can recite the Al-Quran. Most teachers prefer to use speech-based communication methods when teaching the Al-Quran to those hearing-impaired pupils who can read.

Question: How do you plan to teach the Al-Quran to pupils with various hearing disabilities?

"For those who can speak, usually they are not confident to speak or to recite. They prefer to follow other pupils who manage to do so." (T1)

"According to learning the Al-Quran in the Islamic Education syllabus, special needs pupils with hearing disabilities must be taught how to recite." (T2)

"They have to speak and recite the Quran." (T3)

"Like other typical pupils, they must recite repetitively" (T3)

"Those who can listen, they will follow the recitation. I will use the sign language based on the text book for those who are unable to listen." (T4)
"For those who can recite, I will teach them the Talaqqi too." (T4)

Respondents O1, an officer in the Islamic and Moral Education Unit of the Special Education Division, also emphasized this method for students who manage to speak.

"We used to teach recitation only to pupils who are able to speak by training them to spell the Quranic letters." (O1) "For those pupils with hearing impairment or deaf, we will give some space for the teachers to follow the syllabus. However, they are eligible to use speech therapy method during the lesson." (O1)

"There will be a high number of deaf pupils who can recite the Quran by themselves if the teacher uses the speech therapy effectively. Most of the time, we mostly use codes and signs." (O2)

"We will strengthen the Quranic pronunciation for those who are able to speak." (O2)

\section{b. Manually Coded Malay}

All the respondents stated they used the Manual Coded Malay (KTBM) as the main method in teaching the Al-Quran to the special needs' pupils with hearing disabilities. This code is also referred to as the Coded Malay Language which is a form found in Ethnologue. This hand code is derived from the American Sign Language, with the addition of some local alerts, and grammar alerts representing additional nouns and verbs in Malay. This hand codes were originally used in special education schools to teach the Malay language to the deaf pupils. However, the Ministry of Education Malaysia has set the Manually Coded Malay as a code of sign language in other subjects including the Al-Quran which is a component in Islamic Education.

Question: What is the method of communication used in the study of the Quran?

"I use Manually Coded Malay to teach them." (T1)

"We usually use text book. There are code signs in text books where pupils can learn from." (T2)

"I use Manually Coded Malay in teaching the Quran" (T3)

"All teachers use manual code to teach special needs pupils with hearing disabilitiest.” (T4)

"Usually we use text books that contain Manually Coded Malay.” (T5)

In Malaysia, the main teaching method of communication in 'Special Education Intergrated Programme' (PPKI) and 'Special Primary Schools' (SKPK) is the Manually Coded Malay. The Manually Coded Malay has a specific system for controlling the construction of structures, the sentences and meanings (Zulkifley 1994). The Manually Coded Malay is the only form of hand signs that the Malaysian government recognizes as the language of communication for the deaf and dumb in the government schools. The Manually Coded Malay is a verbal translation of the visual. It was introduced by the Ministry of Education Malaysia (MOE) in 1985. The religious codes were introduced in 1988. It is constantly 
edited and refined when utilizing the grammar, and principles of the Malay language. It is carried out with the Total Communication (Bahagian Sekolah, KPM 1995).

\section{c. Malaysian Sign Language}

Some teachers were interviewed using the Malaysian Sign Language. However, the use of the Malaysian Sign Language in the teaching of the Al-Quran is just peripheral. This is due to the Manually Coded Malay is the main method used in the 'Special Education Intergrated Programme' (PPKI) and the 'Special Primary Schools' (SKPK).

Question: Is the hand codes available sufficient enough to teach the Al-Quran to the pupils?

"It depends on the situation. I will refer to other references such as the Malaysian Sign Language if the particular code or sign are not available in the Manually Coded Malay." (T2)

"No, it is not enough. Some of the words are not available in Manually Coded Malay. Hence, I need to refer to the Malaysian Sign Language.” (T3)

There are some opinions which stated Malaysian Sign Language is the main language used among the deaf community in Malaysia in their daily life (Lim, 2006). Malaysian Sign Language is a common language spoken in most places in Malaysia and has many accents, varying between each state. The Disability Act 2008 stated the Malaysian Sign Language is the official language of the Deaf community in Malaysia. Malaysian Sign Language is a non-grammar language of the languages in the world. It differs from the English or Malay structures. Malaysian Sign Language has its own grammar that focuses more on what the deafs can see. It is agreed that Malaysian Sign Language is not suitable in the learning and teaching of either the English or Malay language. However, the Malaysian Sign Language is very useful for the deafs' understanding.

According to Mohammed Sazali Shaari (2004), Malaysian Sign Language is a symbol of the identity of many deaf Malaysians who are rich in culture because their gestures are based on their way of life and are not influenced by any external elements. Based on a study conducted by Abdullah Yusoff dan Che Rabiaah Mohamed (2009), they said if this is certified by a recognizing body, Malaysian Sign Language will be the most useful medium of transition and receiving information for the deaf community especially in education. In fact, the use of the Malaysian Sign Language indirectly has the potential to provide a proper religious education to the deaf community, especially in teaching the Fardu Ain subject in schools (Mohd Huzairi Awang, 2010).

\section{d. Total Communication}

As been described previously, the first method of communication since Special Education was introduced in Malaysia, was oral. However, beginning in 1978, when the Total Communication was introduced (Abdullah 2001), it included speech, Manually Coded Malay, facial expressions, lip reading, body language and finger spelling
Question: What are the approaches used in teaching reading, remembering and understanding the Al-Quran?

"We will use our voice and sign language simultaneously." (T2)

"We show the word using Total Communication including facial expressions." (T3)

Special needs pupils with partial hearing loss and speech skills would be taught to read just like any other normal pupil. Since some of these pupils with partial hearing loss are unable to hear properly among themselves, teachers need to teach using the Total Communication approach which includes speech and gestures or hand codes. The use of Total Communication is encouraged in teaching these special needs pupils with hearing loss as stated by $\mathrm{O} 2$ in the Curriculum Development Sector, which states:

"In teaching, we emphasized on Total Communication. So, we need to stress simultaneously the sign language and pronunciations. We need to teach pronunciations and speech at the same time using sign language called the Total Communication."

\section{Discussion}

One of the components in Islamic Education is learning the Al-Quran. Some special needs pupils with hearing disabilities have speech problems. So the teaching and learning of the Al-Quran is not easy for them. In this case, firstly pupils must be given speech therapy to enable them to be taught to recite the Al-Quran. Pupils with partially hearing loss can be taught to speak the speech components such as articulation, lip reading and auditory training using the amplication tools (Saadiah Ahmad, 1990:4), thus they will be taught to recite the Quran.

In addition, there are of course, several issues and challenges in communication when teaching the Al-Quran to these special needs pupils:

\subsection{The Skills in Handwriting and Sign Language}

According to Lourghan (2013) the sign language is used as the primary form of communication to convey something or teaching to the deaf community. Communication skills especially in the use of handwriting and gestures are important, especially to teach the Al-Quran to the special needs pupils with hearing impairment. The Al-Quran's verses are in Arabic which is a foreign language and a second language in Al-Quran education.

Question: Are there any courses or training you have attended during your service in teaching special needs pupil with hearing impairment?

"There are no courses or training that I attended at the moment. I learned from the textbook. I also self-learned with the help of other teachers and pupils who have the knowledge." (T2)

"I admit I am not an expert and still learning." (T3) 
"Not yet for training and courses for sign language". (T4) "Every Wednesday, it is compulsory for teachers and the management staff to attend the sign language class, beginning at 1:00 p.m. until 1:30 p.m. It is organized by teachers who are experts in sign language." (T5)

However, not all Islamic Education teachers are qualified to teach the Al-Quran to the special needs pupils with hearing disabilities. Despite mastering the Al-Quran, they have to know and master the teaching method of the manually coded or sign language which is one of the communication medium in the teaching and learning of the deafs. This finding is supported with the interview with $\mathrm{O} 1$ from the Islamic and Moral Education Unit, Special Education Division.

Question: In your opinion, what are the characteristics, a teacher should have when teaching the $\mathrm{Al}$ - Quran to the special needs pupils with hearing disabilities?

"The basic knowledge they should have is the Manually Coded Malay. We use widely the Manually Coded Malay when communicating with special needs pupils with hearing disabilities." $(\mathrm{O} 1)$

"Teachers who are experts in sign language would be able to teach pupils very well. However, it depends on the school's management to train their teachers on the sign language." (O1)

"Training the teachers are the vital process at the moment" (O1)

The same goes to the $\mathrm{O} 2$ who emphasized the teachers' responsibility to strive and improve their skills in teaching the Al-Quran

"That will be the teacher's responsibility even if Islamic Education is not their teaching subject.

They have to learn and master the skills in teaching special needs pupils." $(\mathrm{O} 2)$

\subsection{The differences between Manually Coded Malay and Malay Sign Language}

Based on the result of this study, there is a difference between the Manually Coded Malay and the Malay Sign Language. All teachers who participated in the interview used the Manually Coded Malay and some of them used the Malay Sign Language as an additional method. Manually Coded Malay is the official language used in schools while the Malay Sign Language is used in daily communication. The Malaysian Federation of the Deaf (MFD) has requested to use the Malaysian Sign Language as a whole since it has been recognized as the official language for the deafs ((Disability Act 2008: 8).

Question: Can pupils understand the sign language used?

"There are a huge number of pupils from MFD in

Malaysia. They are also questioning why there are different sign languages used in schools. We told them to use Manually Coded Malay while in school but use the Malay Sign Language when outside the school." (T1)

\subsection{Lack of Manually Coded Malay and Sign}

Although the methods of communication in the Manually Coded Malay and the Malay Sign Language are used by some teachers to improve pupils' learning the Al-Quran, there are still some words or terms that cannot be interpreted. This is because some of the words or terms are very new to the deafs especially for the special needs pupils with hearing impairment.

Question: What is the communication problem in teaching the Al-Quran to special needs pupils with hearing impairment?

"There are insufficient codes in the Manually Coded Malay and the Malay Sign Language" (G1)

"Not enough codes. Some of the words are not available in the Manually Coded Malay book. I need to refer to the Malaysian Sign Language." (T3)

As a result, the lack of proper codes or sign language in teaching the Al-Quran will impact the bad result for the special needs pupils with hearing disabilities. According to Mohd Huzairi Awang (2010), it was found that most deaf pupils were not interested, often avoiding in attending the Fardu Ain classes, and they had difficulty in understanding the abstract terms in Fardu Ain Basic Learning (PAFA). This finding was supported by Siti Muhibah's opinion, a previous researcher. Siti Muhibah (2010) stated the difficulty in understanding the subject Fardu Ain was due to the lack of skills in the sign language among teachers, no relevant religious signs and no method that was suitable to teach Fardu Ain to deaf pupils

Therefore, the problem faced by pupils with hearing disabilities in the PAFA learning process is certainly the same problem they faced in studying the Al-Quran. This is because most of the terms in both subjects are in Arabic. As explained earlier, one of the issues in delivering Islamic Education to this group is the lack of appropriate and easy-to-understand handwriting or sign language. If there is no proper use of sign language in teaching the Al-Quran, the special needs pupils with hearing impairment would be less interested in learning as they did not understand the content taught by the teachers (Cooper, Sherly, Jody, Cripps, \& Joel, 2013).

\subsection{Alternative Methods}

Learning the Al-Quran requires a variety of communication methods and teachers should not follow a single method of teaching. This is based on the diverse background of the pupils with varying levels of ability and speech who are present in one classroom, especially in the Special Education Intergrated Programme (PPKI) and the Special Primary Schools (SKPK). Due to lack of codes and sign forms suitable for each word, the teachers are given the 
choice to use any method that they feel suitable to ensure the vision and objective in teaching the Al-Quran are achieved through reading, fluency and understanding of the verses.

Question: How do you teach if the codes or signs are not enough?

"We will find similar words, use photos or spell the words for them." (T1)

"We spell for them using signs if they cannot speak and recite." (T1)

"The pupils who cannot speak are not forced with the implemented method. We will not force them if they can't." (O1)

"We only use the Manually Coded Malay to help deaf pupils recognize alphabet." (O1)

"We give flexibility to the teachers to identify any suitable method during lessons." (O2)

"We are not specific, we have agreed and eligible to combine Manually Coded Malay and Malay Sign Language." (O2)

To achieve the goals and learning objectives of the Al-Quran lessons among the special needs' pupils with hearing disabilities, teachers can use any method of communication mentioned previously. Teachers are allowed to use any communication method such as finger spelling, hand writing or information technology since there is no specific method implemented at any one time.

\section{Conclusions}

Communication in teaching the Al-Quran to the special needs pupils with the hearing disabilities should not be taken lightly. The goals and learning objectives in teaching the Al-Quran would not be achieved without effective delivery by the teachers. Although the special needs pupils have a variety of hearing disabilities, they however do have the potential and the chance to master the Al-Quran as a Muslim. Teaching these pupils requires an appropriate system of communication and cautious planning by the teachers to ensure the Al-Quran learning outcomes are achieved. There are a variety of communication methods for the special needs' pupils with hearing impairment, and therefore, there should not be an issue in determining which method is the most effective. Based on education regulations, the use of the Manually Coded Malay is the main method that should be prioritized in the 'Special Education Intergrated Programme' (PPKI) and 'Special Primary Schools' (SKPK). The use of the Malaysian Sign Language allows for improvement in pupils' understanding. For the pupils who managed to speak, teachers can use the oral method or speech therapy to ensure they can train themselves to read the Al-Quran better. Teachers are encouraged to use the Total Communication method in the class with deaf pupils as well as for those with partial hearing loss to ensure they can understand the Al-Quran. As a recommendation, by training the teachers and attending courses related to teaching special needs pupils with hearing disabilities, they can acquire effective communication needed in helping these pupils.

\section{Acknowledgements}

This paper was fully supported by Research Grant of Universiti Kebangsaan Malaysia: GUP-2016-073.

\section{REFERENCES}

[1] Abdullah Yusuf. (2001). Kecacatan komunikasi berkaitan dengan pendidikan, bahasa dan kebahasaan orang pekak. Jurnal Dewan Bahasa 1 (9): 29-36.

[2] Abdullah Yusoff \& Che Rabiaah Mohammad (2009) Recognising language of the deaf community: The concepts of communication, language, speech, signing and their relationship with the means of communication used by deaf people. Pembentangan dalam International Seminar of Sign Language Research, Universiti Malaya, Kuala Lumpur, 30-31 May 2009.

[3] Akta Pendidikan. (1996). Akta 550. Undang-Undang Malaysia. Cetakan Semula. Pesuruhjaya Penyemak Undang-Undang, Malaysia.

[4] Akta Orang Kurang Upaya. (2008). Akta 685. Undang-Undang Malaysia. Versi Atas Talian Teks Cetakan Semula Dikemas Kini.

[5] Antia, S. D. (2007). Can deaf and hard of hearing students be successful in general education classrooms? [Electronic Version]. Teachers College Record. Retrieved February 5, 2007, from http://www.tcrecord.org.

[6] Antia, S. D., Sabers, D., \& Stinson, M. S. (2007). Validity and reliability of the Classroom Participation Questionnaire with deaf and hard of hearing students in public schools. Journal of Deaf Studies and Deaf Education, 12, 158-171.

[7] Asmawati Suhid, Fathiyah Mohd. Fakhruddin, Samsilah Roslan, Lukman Abdul Mutalib dan Mohd. Aderi Che Noh. (2014). Private Islamic Primary School Teachers' Commitment in Human Capital development in Malaysia. Mediterranean Journal of Social Sciences, Vol. 5, 27, 2014.

[8] Bee, H. (1995). The developing children. Ed. semak. New York: College Publisher Company.

[9] Bernice Burnip. (2002). Communication Skills. Dalam Loise Porter. Educating Young Children with Special Needs. New South Wales, Australia: Allen Unwin.

[10] Bushra Akram \& Rukhsana Bashir. (2013). Special Education and Deaf Children in Pakistan: An Overview. Journal of Elementary Education, Vol.22, No. 2 pp.33-44.

[11] Carol Marchetti, Susan Foster, Gary Long \& Michael Stinson. (2012). Crossing the Communication Barrier: Facilitating Communication in Mixed Groups of Deaf and Hearing Students. Journal of Postsecondary Education and Disability, 25(1), 51 - 63. Rochester Institute of Technology.

[12] Ciara Kelly, Gary Morgan, Megan Freeth, Michael Siegal, 
Danielle Matthews. (2019). The Journal of Deaf Studies and Deaf Education, Volume 24, Issue 3, July 2019, Pages 245254.

[13] Chua Tee Tee. (1976). Communication for hearing handicapped in Malaysia. Communication for the hearing impaired, an international prospective. Baltimore: University Park Press.

[14] Chua Tee Tee. (1980). Impilication of using total communication of teaching the deaf in Malaysia. Suara Pendidik. 6(2): 2-9.

[15] Cooper, Sheryl B., Jody H., Cripps, \& Joel I. (2013). Service-learning in deaf studies: Impact on the development of altruistic behaviors and social justice concern. American Annals of The Deaf, 157(5), 413-427.

[16] Donald A. Grushkin. (2006). The More Things Change The Linguistics of American Sign Language: An Introduction. The Journal of Deaf Studies and Deaf Education, Volume 11, Issue 2, Spring 2006, Page 269.

[17] Fischer, S. (1982). Sign language and manual communication. Deafness and Communication assesment and training: 90-1-6.

[18] Kartini Ahmad. (1997). Auditori verbal workshop for Asia Pacific region. Institut Kefahaman Islam. Kuala Lumpur, 24-26 Oktober.

[19] [19]Khatoon, A. (2003). A historical and evaluative study of special. Doctoral Thesis: Special Education Department, University of Karachi, Karachi.

[20] Lim, L. (2006). Understanding deaf culture Malaysian Perspectives. Kuala Lumpur: Majudiri Y Foundation for the Deaf.

[21] Loughran, S. (2013). Cultural identity, deafness and sign language: A postcolonial approach. LUX: A Journal of Transdisiciplinary Writing and Research form Claremont Graduate University, 2(1), 1-8.

[22] Mat Redhuan Samsudin, Tan Tse Guan, Anuar Mohd Yusof, Azwady Mustapha. 2018. Effectiveness Malaysian Sign Language Mobile Application in Teaching and Learning for Deaf and Mute Students. Advanced Journal of Technical and Vocational Education, 2(1): 19-24, 2018 e-ISSN:2550-2174.

[23] Mohd Huzairi Awang. (2010). Persepsi pelajar bermasalah pendengaran terhadap pembelajaran asas fardhu ain: Cabaran terhadap guru. Proceedings of the 4th International Conference on Teacher Education: Joint Conference UPI \& UPSI (pp. 240 - 250).

[24] Mohamed Sazali Shaari. (2004). Budaya orang pekak. Kertas persidangan keluarga Pekak bahagia. Hotel Crown Princess, Kuala Lumpur, 13 Ogos 2004.

[25] Ns. Mardiyanti and Luh Putu Suta Haryanthi. (2018). Challenges on Learning Islam among Deaf Muslim in an Indonesian Context: Deaf Teachers Perspective. International Medical Journal Malaysia, Vol: 17, Pages: 17-21.

[26] Patsy Kam. (1995). One who has beaten the odds. The Star, 4 disember: section $2 / 7$.

[27] Saadiah Ahmad. 1990. Kanak-kanak Bermasalah Komunikasi. Prosiding Seminar Kebangsaan Pendidikan Kanak-kanak Dengan Keperluan Khas: Cabaran Kini, Bangi: Fakulti Pendidikan UKM.
[28] Safani Bari et. al. (2005). "Kaedah Komunikasi Seluruh dan Pencapaian Murid-murid Bermasalah Pendengaran Dalam Peperiksaan" (Laporan Penyelidikan Fakulti Pendidikan UKM).

[29] Shirin D. Antia, Patricia B. Jones, Susanne Reed \& Kathryn H. Kreimeyer. (2009). Academic Status and Progress of Deaf and Hard-of-Hearing Students in General Education Classrooms. Journal of Deaf Studies and Deaf Education 14(3): 293-311. Published by Oxford University Press, University of Arizona. Published by Oxford University Press, University of Arizona.

[30] Simser, J.I. (1997). Bengkel auditori-verbal untuk Asia pasifik. Prinsip-prinsip Auditori-Verbal. Institut Kefahaman Islam. Kuala Lumpur, 24-26 Oktober.

[31] Siti Muhibah Nor. (2010). Kesukaran pemahaman murid-murid bermasalah pendengaran terhadap mata pelajaran Pendidikan Islam. Dlm. Proceedings First Annual Inclusive Education Practices Conference (hlm. 122 -130).

[32] Warta Kerajaan Persekutuan. (2013). Peraturan-peraturan Pendidikan (Pendidkan Khas) 2013.

[33] Wilbur, R. B. (2013). Changing how we think about sign language, geesture, and agreeement. Sign Language and Linguistics, 16(2), 221-258.

[34] Zohreh Ghari. (2016). The Cognitive, Psychological and Cultural Impact of Communication Barrier on Deaf Adults' Content of Speech in Iran. Journal of Deaf Studies and Hearing Aids. Vol: 4, Issue: 3, ISSN:2375-4427.

[35] Zulkifliey Hamid. (1994). Pembelajaran dan pengajaran bahasa. Kuala Lumpur: Dewan Bahasa dan Pustaka. 